\title{
United Kingdom Patent Decisions 2018
}

\author{
Robyn Trigg
}

Published online: 25 February 2019

(C) The Author(s) 2019

\begin{abstract}
This report highlights the main UK patent decisions from 2018, including: a major Supreme Court decision concerning sufficiency, more specifically plausibility, and infringement in relation to second medical use claims; Court of Appeal decisions on global FRAND licences and FRAND injunctions, applying the Actavis v. Eli Lilly questions concerning the doctrine of equivalents, enablement, claim construction and infringement, novelty of overlapping numerical ranges, and obviousness; and Patents Court decisions concerning interim applications, a jurisdiction challenge in the context of a FRAND licensing dispute, obviousness/inventive step, and injunctive relief.
\end{abstract}

Keywords Sufficiency · Plausibility $\cdot$ Second medical use $\cdot$ Infringement $\cdot$ Doctrine of equivalents · FRAND $\cdot$ Jurisdiction

Cases Actavis UK Ltd v. Eli Lilly \& Co [2018] All E.R. 171; Aldi Stores Ltd v. WSP Group plc [2008] W.L.R. 748; AP Racing Ltd v. Alcon Components Ltd [2013] EWPCC 3; AP Racing Ltd v. Alcon Components Ltd [2014] R.P.C. 27; AP Racing Ltd v. Alcon Components Ltd [2017] EWHC 248 (IPEC); AP Racing Ltd v. Alcon Components Ltd [2018] EWCA Civ 1420; Arnold v. National Westminster Bank Plc (No.1) [1991] 2 AC 93; Clearswift Ltd v. Glasswall (IP) Ltd [2018] EWHC 2442 (Pat); Conversant Wireless Licensing SARL v. Huawei Technologies and Ors [2018] EWHC 808 (Pat); Edwards Lifesciences LLC v. Boston Scientific Scimed Inc [2017] EWHC 405 (Pat); Edwards Lifesciences LLC v. Boston Scientific Scimed Inc [2017] EWHC 755 (Pat); Edwards Lifesciences LLC v. Boston Scientific Scimed Inc [2018] F.S.R. 29; Edwards Lifesciences LLC v. Boston Scientific Scimed Inc [2018] EWHC 1256 (Pat); G0002/98; Generics (UK) Ltd (t/a Mylan) v. Warner-Lambert Co LLC 
[2016] R.P.C. 3; Generics (UK) Ltd (t/a Mylan) v. Warner-Lambert Co LLC [2017] R.P.C. 1; H Lundbeck A/S v. Norpharma SpA [2011] EWHC 907 (Pat); Hospira UK Ltd v. Genentech Inc. [2017] R.P.C. 13; Hospira UK Limited v. Cubist Pharmaceuticals LLC [2017] R.P.C. 10; Hospira UK Limited v. Cubist Pharmaceuticals LLC [2018] EWCA Civ 12; Huawei Technologies Co. Ltd v. ZTE Corp., ZTE Deutschland GmbH (Case C-170/13); Icescape Ltd v. Ice-World International BV [2018] EWCA Civ 2219; Illumina Inc. v. Premaitha Health Plc [2017] EWHC 2930 (Pat); Illumnia Inc. v. Premaitha Health Plc [2018] EWHC 615 (Pat); Jushi Group Co Ltd v. OCV Intellectual Capital LLC [2017] EWHC 171 (IPEC); Jushi Group Co Ltd v. OCV Intellectual Capital LLC [2018] EWCA Civ 1416; MedImmune Ltd v. Novartis Pharmaceuticals UK Ltd [2013] R.P.C. 27; Merck Sharp \& Dohme Ltd v. Ono Pharmaceutical Co Ltd [2015] EWHC 2973 (Pat); Owusu v. Jackson [2005] Q.B. 801; Pozzoli SpA v. BDMO SA [2007] F.S.R. 37; Regeneron Pharmaceuticals Inc. v. Genentech Inc. [2013] R.P.C. 28; Regeneron Pharmaceuticals Inc. v. Kymab Ltd \& Novo Nordisk A/S [2016] EWHC 87 (Pat); Regeneron Pharmaceuticals Inc. v. Kymab Ltd \& Novo Nordisk A/S [2018] EWCA Civ 671; Spiliada Maritime Corp v. Cansulex Ltd [1987] AC 460; Synthon BV v. SmithKline Beecham Plc (No. 2) [2006] All E.R. 685; Unwired Planet International Ltd v. Huawei Technology Co Ltd [2017] EWHC 711 (Pat); Unwired Planet International Ltd v. Huawei Technology Co Ltd [2018] EWCA Civ 2344; WarnerLambert Co LLC v. Generics (UK) Ltd (t/a Mylan) [2018] UKSC 56.

\section{Legislation Patents Act 1977 (UK)}

\section{Warner-Lambert Co LLC v. Generics (UK) Ltd (t/a Mylan)}

The most important patent decision of 2018 was the Supreme Court's decision in Warner-Lambert Co LLC v. Generics (UK) Ltd (t/a Mylan) ${ }^{1}$ where it considered the role of plausibility in the statutory test for insufficiency and infringement in relation to second medical use claims. The case was the final decision in the lengthy dispute between Pfizer (parent company of Warner-Lambert) and Generics (UK) Ltd (trading as Mylan) and Actavis Group concerning the validity and infringement of Warner-Lambert's patent for the drug Lyrica ${ }^{\circledR}$ (Pfizer's brand name for pregabalin).

The patent uses a "Swiss" form claim (i.e. it contains claims to the use of a compound in the production of a medicine for use in treating a particular therapeutic indication) for the use of pregabalin for the treatment of pain (claim 1). Dependent claim 2 was limited to inflammatory pain and dependent claim 3 was limited to neuropathic pain. Actavis manufactures a pregabalin generic called Lecaent ${ }^{\circledR}$. The Supreme Court unanimously dismissed Warner-Lambert's appeal, finding that the patent was insufficient and, even if the claims had been found valid, they would not have been infringed. The Court also discussed the test for assessing infringement in second medical use cases and overall preferred the "outward presentation" test (Lord Hodge and Lord Briggs disagreed). The Supreme Court also reached a unanimous decision with regards to construction of the terms "pain" and

\footnotetext{
${ }^{1}[2018]$ UKSC 56.
} 
"neuropathic pain" and found that Warner-Lambert's post-trial amendment application was an abuse of process.

In 2014, Mylan and Actavis brought separate revocation claims against the patent, alleging that the claims were insufficiently disclosed. Warner-Lambert brought an infringement action against Actavis in the same year. Warner-Lambert was unsuccessful in the Patents Court ${ }^{2}$ where claims 1 and 3 were held insufficient and, even if the claims were valid, they would not have been infringed. In light of the Patents Court decision, Warner-Lambert made a post-trial amendment application seeking to limit claim 3 to peripheral neuropathic pain only. In 2015, the Court of Appeal upheld the findings of the Patents Court and ruled that WarnerLambert's post-trial amendment application was an abuse of process. ${ }^{3}$

The major issues before the Supreme Court were: (i) what role does plausibility play in the statutory test for insufficiency; and (ii) how should infringement of "Swiss" form claims be determined.

The sufficiency requirement in patent law (and the related concepts of enablement and plausibility) was designed to ensure that a patentee provides full public disclosure of its invention in return for a granted patent. In the UK the legislative basis for sufficiency is in Sec. 72(1)(c) of the Patents Act 1977 (PA 1977), which states that a patent can be revoked if "the specification of the patent does not disclose the invention clearly enough and completely enough for it to be performed by a person skilled in the art". Thus, the invention in the patent must be sufficiently disclosed or else the patent is at risk of being found invalid. The European Patent Convention (EPC) has corresponding sufficiency provisions at Arts. 83 and 100(b).

A patent may be insufficient for lack of enablement, i.e. the skilled person would not be able to carry out the invention. The UK Court of Appeal reasserted what is considered to be an enabling disclosure in Regeneron Pharmaceuticals Inc. $v$. Kymab Ltd \& Novo Nordisk $A / S,{ }^{4}$ discussed further below. Whilst this criterion is relevant to an invention for a new product or process, it is not necessarily relevant in the case of second medical use patents.

Per UK case law, a patent may be insufficient where an invention is not enabled across its entire scope. Thus, for example, if a patent claims a drug for treating cancer, it may not be sufficiently disclosed across its entire scope if the specification only provides examples of the drug working in one type of cancer and not others. In order for a claim to be sufficiently disclosed, the claim must be enabled across its entire scope, i.e. a skilled person would not find it unduly burdensome to use the drug to treat any type of cancer. Furthermore, the claim must also be plausible to a skilled person from the data provided in the specification that the invention will work for the stated purpose. To use the above example, it is plausible that the drug would work against any type of cancer, for example, this could be because the mechanism of action of the drug is applicable to any type of cancer. ${ }^{5}$

\footnotetext{
${ }^{2}$ Generics (UK) Ltd (t/a Mylan) v. Warner-Lambert Co LLC [2016] R.P.C. 3.

${ }^{3}$ Generics (UK) Ltd (t/a Mylan) v. Warner-Lambert Co LLC [2017] R.P.C. 1.

4 [2018] EWCA Civ 671.

5 See Merck Sharp \& Dohme Ltd v. Ono Pharmaceutical Co Ltd [2015] EWHC 2973 (Pat).
} 
In the case of second medical use patents, without some form of disclosure of how or why the existing product is expected to work for the new purpose, it would be possible to speculatively patent the manufacture of known products/compounds, without actually inventing anything and hoping that further trials later show the product is effective for the newly patented purpose. Thus, previously the Court of Appeal had agreed with the Patents Court finding that claims 1 and 3 of the Patent were insufficient as, based on the data in the specification derived from a mouse model of inflammatory pain, it was not plausible that pregabalin would be effective in treating any type of pain (claim 1) or central neuropathic pain (claim 3). Conversely, it was found that the treatment of peripheral neuropathic pain was plausible because both inflammatory pain and peripheral neuropathic pain share a central sensitisation component.

The Supreme Court held by majority (Lord Sumption, Lord Reed and Lord Briggs) that the disclosure in the specification supports claims that relate to inflammatory pain but not to any kind of neuropathic pain. The Supreme Court dismissed Warner-Lambert's appeal that the claim to the use of pregabalin for the treatment of central neuropathic pain was sufficiently disclosed and upheld Actavis and Mylan's appeal that the treatment of peripheral neuropathic pain was also insufficiently disclosed. The Court found that the mouse models used to the provide the data in the specification were only relevant to inflammatory pain. Lord Sumption stated that just because inflammatory pain and peripheral neuropathic pain may have a common component of central sensitisation "does not prove that they have a common cause". 6

Lord Sumption disagreed with the Court Appeal that "the slimmest of evidence" is all that is necessary to plausibly predict a therapeutic effect and stated that "the specification must disclose some reason for supposing that the implied assertion of efficacy in the claim is true". ${ }^{7}$ He then went on to conclude that: "The disclosure did not contribute any knowledge of the art capable of justifying a claim to a monopoly of the manufacture of pregabalin for the treatment of neuropathic pain of any kind." 8

Lord Sumption said that plausibility with regards to second medical use claims

... does not mean that it [the claimed invention] must work for all patients suffering from that condition, or work on every occasion when it is applied by way of treatment. But it does mean that where the condition identified embraces a number of different pathologies, and the claim is constructed as asserting the efficacy of the product for each of them, the assertion must be plausible in relation to them all. ${ }^{9}$

Lord Hodge and Lord Mance disagreed with Lord Sumption's approach to plausibility; Lord Mance stated that Lord Sumption's test "imposes too high a threshold, and imposes a burden on a patentee which the case law of the Board of

\footnotetext{
6 Supra note 1, para. [50].

7 Supra note 1, para. [36].

8 Supra note 1, para. [54].

9 Supra note 1, para. [39].
} 
Appeal of the European Patent Office does not justify". ${ }^{10}$ Lord Mance said that the requirement for the specification to disclose some reasoning for assuming that the implied assertion of efficacy in a claim is true "risks being read as a requirement that the plausibility of the claim must appear to be established prima facie through scientifically cogent reasoning or experimental evidence set out in the specification". ${ }^{11}$ What is clear is that the Supreme Court has confirmed plausibility as part of the test for sufficiency of second medical use claims; what remains to be seen is whether this hurdle has been set too high.

The Supreme Court also considered the issue of construction. The Court of Appeal had previously rejected Warner-Lambert's argument that the term "pain" would be understood by the skilled person as meaning something other than the ordinary meaning of pain. The Court of Appeal had also held that the term "neuropathic pain" in claim 3 would include both central and peripheral neuropathic pain; it was found that a skilled person would not understand claim 3 as excluding central neuropathic pain. In the Supreme Court, Warner-Lambert argued that the Court of Appeal had ignored expert evidence in reaching these conclusions. However, the Supreme Court unanimously agreed with the Court of Appeal's finding that claim 1 extended to all types pain and that claim 3 extended to all types of neuropathic pain.

The Supreme Court also agreed with both the Patents Court and the Court of Appeal that Warner-Lambert's post-trial amendment application to limit claim 3 to peripheral neuropathic pain only, was an abuse of process as there was no good reason why this had not been raised earlier at trial.

The Supreme Court also dealt with the issue of infringement in respect of claims 1 and 3. As noted above, both claims 1 and 3 had previously been found to be insufficient by the Court of Appeal but Floyd LJ had considered the issue obiter. Floyd LJ had provided a clear test for assessing infringement of "Swiss" claims: the court should assess whether the alleged infringer knew or could foresee that at least some of the prescriptions written generically for the claimed drug for the claimed indication would be fulfilled with the generic. Floyd LJ said that the use of a skinny label (i.e. not including the claimed patented indication on the label) "cannot conceivably be sufficient to negative the intention". 12 Instead, he said, "the intention will be negatived where the manufacturer has taken all reasonable steps within his power to prevent the consequences occurring". ${ }^{13}$

The Supreme Court, by majority, dismissed Warner-Lambert's appeal on infringement. Lord Sumption, Lord Reed, Lord Hodge and Lord Briggs found that if claims 1 and 3 had been valid, they would not have been infringed; however, each Lord differed in their reasoning. Lord Sumption and Lord Reed agreed that the subjective intention of the alleged infringer is not relevant and that the sole test of infringement is whether the product, including any labelling or accompanying leaflets, is presented as suitable for the uses which benefit from patent protection (i.e. an "outward presentation" test). Lord Hodge and Lord Briggs disagreed and

\footnotetext{
${ }^{10}$ Supra note 1, para. [193].

11 Supra note 1, para. [195].

12 Supra note 3, para. [207].

13 Supra note 3, para. [208].
} 
endorsed the view of Mr Justice Arnold in the Patents Court that the test is whether the alleged infringer subjectively intended to target the patent protected market. Lord Mance sided with Lord Sumption and Lord Reed and ruled that the subjective intention of the alleged infringer cannot be a suitable test for infringement. Lord Mance does, however, acknowledge the possibility that there might be extreme cases where the "outward presentation" test does not afford patentees sufficient protection but he leaves open this position, preferring not to say more as he is commenting obiter. This is perhaps a warning to generic companies to act responsibly in how they outwardly present their products. Lord Mance warns

[i]t may be going too far in favour of generic manufacturers to suggest an absolute rule that a generic product, prepared, presented and put on the market, must always be viewed in isolation by reference only to its own packaging and instructions, and without regard to the realities or of the market for which it is prepared and into which it is being released. ${ }^{14}$

The "outward presentation" test is clearly favourable to generics, giving them a framework for safely launching into second medical use markets. As Lord Mance notes at the end of the judgment, "[t]he protection afforded by a Swiss form patent, analysed as protecting a process in the way English law analyses it, is valuable, but necessarily limited". ${ }^{15}$ It is likely that the scope of second medical use protection will be questioned further in the future and we will have to watch this space to see which direction it travels in.

\section{Illumina Inc. v. Premaitha Health Plc}

An interesting interim decision Illumina Inc. v. Premaitha Health Plc ${ }^{16}$ came from Carr $\mathrm{J}$ in the Patents Court dealing with two applications brought by Premaitha for strike out on the basis of abuse of process by Illumina bringing a new claim against Premaitha and summary judgment against Illumina on the basis of issue estoppel. Carr $\mathbf{J}$ dismissed the abuse of process application and allowed the application for summary judgment.

Since 2015, Premaitha and Illumina have been engaged in various patent disputes concerning non-invasive prenatal tests offered by Premaitha. Shortly prior to the trial in the Patents Court, Illumina came to be aware of an additional patent that it wanted to enforce against Premaitha. Due to the extent of the issues to be covered in the 2017 trial, the parties agreed that a new action concerning this new patent could not be accommodated in the 2017 trial. In a judgment also by Mr Justice Carr, Illumina was successful at trial ${ }^{17}$ and after this success, Illumina begun a new action in respect of the newly found patent.

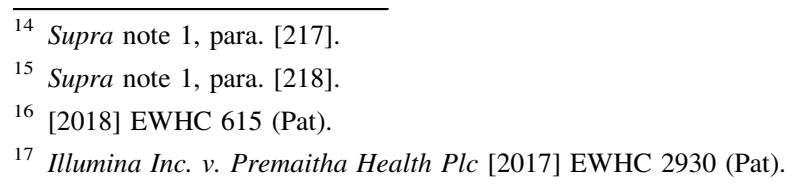


In response to this new action, Premaitha argued that the new action should be struck out as an abuse of process or dismissed as Illumina is not entitled to bring the proceedings as, Premaitha argued, Illumina failed to raise the new action in the previous litigation.

In this judgment, Carr $\mathbf{J}$ set out a summary of the principles concerning abuse of process, ${ }^{18}$ stating that the court must balance the right to a fair trial of the party bringing the proceedings against the unjust harassment or oppression of the party asserting that the new claim is abusive. Carr $\mathbf{J}$ concluded that the relevant question is not whether the new issue could have been raised in previous proceedings, but whether the issue should have been raised earlier. Carr J said that the court will rarely find that a later action is an abuse of process and that it is for the defendant to prove.

Carr $\mathrm{J}$ referred to the Aldi guidelines ${ }^{19}$ concerning abuse of process and the need for parties in litigation to be forthcoming with regard to contemplated future proceedings. The Aldi guidelines state that where a party in proceedings becomes aware of a cause of action which could be brought as part of the ongoing proceedings, the party should raise the issue with the court so that it can be managed fairly for both sides.

Illumina had not brought the new cause of action to the attention of the Court in the previous proceedings, but Carr $\mathbf{J}$ found that this did not constitute a breach of the Aldi guidelines because the parties had agreed that the new action should not be dealt with until after the 2017 trial. Carr J dismissed the reasons put forth by Premaitha as to why it felt the new claim would be oppressive; Carr J stated that the new proceedings were unlikely to be an attack on the decision in the previous proceedings because the new proceedings would likely be on the basis of different common general knowledge. Carr J's judgment affirms that the court requires persuasive evidence of oppressive behaviour by the claimant and that the court will not make abuse of process findings lightly.

With respect to Premaitha's application for summary judgment on the basis of issue estoppel, Premiatha raised the 2017 finding that Illumina did not have standing to sue as it was not an exclusive licensee under the patents being enforced. Carr $\mathbf{J}$ referred to Arnold v. National Westminster Bank Plc $(N o .1)^{20}$ which set out the law on issue estoppel, namely: issue estoppel may arise where an issue necessary to a cause of action has been litigated and decided and subsequent proceedings between the same parties involving a different cause of action but to which the same issue is relevant and one of the parties seeks to readdress the issue.

In the 2017 litigation, Carr $\mathbf{J}$ had held that, under the agreement in question, Illumina was not an exclusive licensee and thus when Illumina attempted to bring the new cause of action on the basis of being an exclusive licensee under the same agreement, issue estoppel arose. Carr $\mathbf{J}$ gave summary judgment against Illumina and its new claim was not allowed to proceed. However, Carr $\mathbf{J}$ said that if Illumina corrected its exclusive licensee issue it could be joined to the case between another

\footnotetext{
18 Supra note 16, paras. [5]-[21].

19 See Aldi Stores Ltd v. WSP Group plc [2008] W.L.R. 748.

20 [1991] 2 AC 93.
} 
claimant and Premaitha. Illumina and Premaitha have since entered into a licensing agreement settling this dispute.

\section{Edwards Lifesciences LLC v. Boston Scientific Scimed Inc.}

Edwards Lifesciences LLC v. Boston Scientific Scimed Inc. ${ }^{21}$ illustrates the Patents Court's willingness to take a tailored approach to injunctive relief based on the facts of the case, including granting a time limited stay of the injunction and providing a carve out for certain patients which is not time limited, albeit with the patentee still receiving a financial remedy on the permitted sales.

In 2015, Edwards commenced a revocation action against one of Boston's patents (EP (UK) 2249254 (EP 254)). Boston then counterclaimed for infringement of EP 254 and another patent (EP(UK) 2926766 (EP 766)) by Edwards' launch of Sapien 3 in 2014, a transcatheter heart valve (THV). At the trial, expert and fact evidence had shown that there are seven THVs approved for use in the UK, and that Sapien 3 constitutes over half of the market. Furthermore, for certain patient subgroups, Sapien 3 is the only treatment option.

HHJ Hacon sitting as a High Court Judge in the Patents Court found that EP 254 was invalid but that EP 766 was valid and infringed. ${ }^{22}$ In light of the judgment, Boston sought an injunction but Edwards opposed this because, it said, there was a public interest in patients receiving the Sapien 3.

At first instance, the HHJ Hacon granted an injunction but stayed it pending appeal, permission having been granted to both parties. ${ }^{23}$ The Court of Appeal dismissed both appeals and remitted the case back to the Patents Court for the issue of the injunction to be determined. ${ }^{24}$

In this decision, the Patents Court reconsidered the issue of the injunction and it granted an initial stay of the injunction for a period of 12 months. Arnold J's reasoning for the stay was that a number of clinicians using THVs would need to be re-trained in order to use an alternative to Sapien 3. Arnold J also gave permission to apply for an extension of this stay if more time is needed to complete the re-training.

In addition to the stay, the Arnold $\mathbf{J}$ allowed an exception to the injunction for patients for whom Sapien 3 is the only viable treatment option. The Court did not impose a time limit on this exception. Both sides had agreed that Sapien 3 devices should be allowed to be supplied to these patients, provided that there is a suitable declaration from the treating clinician stating that in their view Sapien 3 is the only viable device. This case shows the UK courts are willing to take a sensible and pragmatic approach to injunctive relieve tailored to the circumstances at hand.

\footnotetext{
21 [2018] EWHC 1256 (Pat).

22 Edwards Lifesciences LLC v. Boston Scientific Scimed Inc. [2017] EWHC 405 (Pat).

23 Edwards Lifesciences LLC v. Boston Scientific Scimed Inc. [2017] EWHC 755 (Pat).

${ }^{24}$ Edwards Lifesciences LLC v. Boston Scientific Scimed Inc. [2018] F.S.R. 29.
} 


\section{Icescape Ltd v. Ice-World International BV}

Prior to his promotion to the Supreme Court, Kitchin LJ (as he then was) applied the Supreme Court's Actavis questions regarding the doctrine of equivalence and claim construction ${ }^{25}$ in Icescape Ltd v. Ice-World International $B V{ }^{26}$

This case considered whether Ice-World's patent for a mobile ice rink cooling member (EP (UK) 1462 755) was valid and infringed by Icescape. The Court of Appeal first had to consider whether the patent was entitled to priority. The patent disclosed a cooling member which comprised of a standard manifold and longitudinal pipe arrangement, organised into discrete elements. Each element has a feed manifold, a discharge manifold and some longitudinal pipes. In practice, these elements are connected by fluid-tight junctions. The pipes within each element are formed of at least two rigid sections connected by moveable fluid-tight junctions. These moveable fluid-tight junctions allow groups of pipes to be folded against each other for transport. The priority document, however, differed from the patent as it did not explicitly disclose the cooling member having multiple "elements". Thus, the Court of Appeal had to decide whether the disclosure of a cooling member without the multiple element structure (but all other claimed features) was a disclosure of the claimed invention.

The patentee argued that the inventive concept of the patent is the foldable pipes, which was clearly disclosed in the priority document. The patentee further argued that the patent only disclosed an additional diagram which shows a set-up of two elements placed beside each other, known in the common general knowledge, and connected in a conventional way. Thus, the patentee argued, a skilled person would have read the multiple elements feature into the priority disclosure.

Kitchin LJ (as he then was), referring to G2/98 of The Enlarged Board of Appeal of the EPO, concluded that "[t]he claim to priority depends upon the express or implicit disclosure of those features in the priority document and, since there is no such disclosure, the claim to priority must fail". ${ }^{27}$

Even though the patent was found to be invalid by virtue of the patentee's prior use in light of the invalid priority claim, the Court of Appeal still went on to consider infringement and apply the Actavis questions.

At first instance the Patents Court had found that Icescape's cooling system did not infringe Ice-World's patent because, in Icescape's equipment, the feed manifold is not connected to the discharge manifold and the manifolds are arranged in a parallel formation, rather than in series. The Patents Court decision was, however, decided before the Supreme Court's decision in Actavis v. Eli Lilly ${ }^{28}$ and Kitchin LJ (as he then was) said that this decision established a "markedly different" approach to claim interpretation to that which had been previously applied by the UK courts.

Kitchin LJ (as he then was) set out the steps now required for interpreting and determining the scope of patent protection. It must first be asked: (i) does the variant

\footnotetext{
${ }^{25}$ Laid down in Actavis UK Ltd v. Eli Lilly \& Co [2018] All E.R. 171.

${ }^{26}$ [2018] EWCA Civ 2219.

${ }^{27}$ Supra note 26, para. [43].

${ }^{28}$ Supra note 25.
} 
infringe any of the claims as a matter of normal (purposive) interpretation? The Actavis questions laid down by Lord Neuberger must then be applied, as follows: (ii) if the answer to (i) is no, does the variant nevertheless infringe because it varies from the invention in a way(s) which is immaterial? Question (ii) is to be determined by asking three further questions: (a) even though the variant does not fall within the literal (i.e. normal/purposive) meaning of the claims, does the variant achieve substantially the same result in substantially the same way as the invention?, (b) would it be obvious to the skilled person, reading the patent at the priority date, but knowing that the variant achieves substantially the same result as the invention, that it does so in substantially the same way?, and (c) would such a reader of the patent have concluded that the patentee nonetheless intended that strict compliance with the literal meaning of the relevant claim(s) was an essential requirement of the invention? Kitchin LJ (as he then was) stated that in order to establish infringement where there is no infringement by normal (purposive) interpretation, a patentee would have to answer "yes" to questions (a) and (b) and "no" to question (c). ${ }^{29}$

In applying the above approach to the case, Kitchin LJ (as he then was) concurred with the decision of the Patents Court that Icescape's cooling system did not fall within the scope of the claims under normal (purposive) interpretation. It was held that a skilled person would read Ice-World's claim as meaning the elements were connected in series and Icescape's equipment did not follow this set-up.

Kitchin LJ (as he then was) then applied the Actavis questions and answered as follows: (a) yes - Kitchin LJ (as he then was) held that the main inventive concept of Ice-World's patent was the fluid-tight joint members which allowed the equipment to be folded for easier transportation; this was the distinguishing factor over other known cooling equipment. Conversely, Kitchin LJ (as he then was) held that the arrangement of the elements in series was known in the common general knowledge and therefore this element was peripheral to the main inventive concept; (b) yes - Lord Kitchin (as he then was) thought that Icescape's system worked in the same way as the claimed invention and that the arrangement of the elements did not affect the cooling function performed by the apparatus; and (c) no - Lord Kitchin held that the main inventive concept of the patent was not related to the arrangement of the elements and therefore " $[\mathrm{t}]$ here is no reason why the skilled reader would have thought that strict compliance ... was an essential requirement of the invention". 30 Thus, there would have been infringement had the patent been held valid.

In Actavis v. Lilly, ${ }^{31}$ Lord Neuberger decided that a court may rely on the prosecution history to determine the scope of a patent, if doing so would unambiguously resolve a point or if it would be contrary to public interest not to consider the prosecution file. ${ }^{32}$ In this case, Icescape did submit evidence from the prosecution history showing Ice-World's response to a novelty objection raise by

\footnotetext{
${ }^{29}$ Supra note 26, paras. [66]-[67].

30 Supra note 26, para. [74].

31 Supra note 25.

32 Supra note 25, para. [88].
} 
the EPO. Kitchin LJ (as he then was) did not accept this evidence as he said that it was not possible to determine whether the objection raised by the EPO "was a sound one" and whether Ice-World had intended to limit the scope of the claims by its response. ${ }^{33}$ It is clear that the bar is set very high for being able to effectively use prosecution history to answer a question of equivalents and Kitchin LJ (as he then was) held that it was not met in this case. There has yet to be a case where use of the prosecution history has been made.

In conclusion, Kitchin LJ's (as he then was) application of the Actavis questions and his decision in this instance would have benefitted the patentee had the patent not been held invalid. Greater weight and importance is now being given to the substance of the inventive concept espoused by a patent rather than the precise words of the claims.

\section{Regeneron Pharmaceuticals Inc. v. Kymab Ltd \& Novo Nordisk A/S}

Regeneron Pharmaceuticals Inc. v. Kymab Ltd \& Novo Nordisk $A / S^{34}$ is another decision considering insufficiency (enabling disclosures). The Court of Appeal reversed the first instance decision of Carr J which had found that Regeneron's patents (EP 1360287 (EP 287) and divisional EP 2264163 (EP 163)) concerning transgenic VelocImmune mice and methods of creating the same were invalid for insufficiency. ${ }^{35}$ Regeneron's VelocImmune mice are used as a platform for creating antibodies which have a human variable region and a mouse constant region. The Regeneron patents specifically relate to a method for genetically modifying the variable regions of a mouse cell and replacing them with the equivalent human variable genes - either a light chain (VJ) or a heavy chain (VDJ). The method set forth involves cloning a large genomic fragment, containing one or more human $\mathrm{V}$, $\mathbf{J}$ (and optionally D) regions, into a targeting vector (LTVEC), introducing this LTVEC into a mouse cell and using a modification of allele (MOA) assay to screen for successful insertion of the human V, D, and/or J. The specification of the patent also includes an example (Example 3) describing in situ replacement of the mouse variable region (VDJ/VJ) genes with the human counterparts.

In the Patents Court, Regeneron had brought infringement proceedings against Kymab and Novo for infringement of the patents (by virtue of Kymab producing its own transgenic mice) and Kymab and Novo counterclaimed that the patents were invalid on the basis that the claimed invention was not sufficiently disclosed and lacked novelty and inventive step. Carr J rejected Kymab and Novo's novelty and inventive step arguments but held that the patents were invalid and revoked them for lack of sufficiency.

Carr $\mathbf{J}$ found that the patents were insufficient because, in view of expert evidence, the method provided for in Example 3 of the specification could not have been performed by the skilled person at the priority date. The method set out in

\footnotetext{
33 Supra note 26, para. [79].

34 Supra note 4.

35 Regeneron Pharmaceuticals Inc. v. Kymab Ltd \& Novo Nordisk A/S [2016] EWHC 87 (Pat).
} 
Example 3 specified "in situ replacement of V, D and $J$ gene segments of the endogenous locus with orthologous human V, D and J gene segments". Carr J interpreted this as meaning the deletion of at least $100 \mathrm{~kb}$ of mouse sequences (i.e. at least one $\mathrm{V}$, and all $\mathrm{D}$ and $\mathrm{J}$ segments) and the insertion of the equivalent human regions (75 $\mathrm{kb}$ or more). On this interpretation, expert evidence said that the deletion and insertion of pieces of DNA of this size was not possible at the priority date. As such, Carr J concluded that the method and mouse were not sufficiently disclosed.

Regeneron appealed the sufficiency finding but did not challenge the conclusion that the skilled person would have been unable to delete $100 \mathrm{~kb}$ of mouse DNA and insert $75 \mathrm{~kb}$ of human DNA. Regeneron argued that the skilled person would have modified the method set out in Example 3 in order to decrease the size of the human DNA insert by decreasing the number of $\mathrm{V}, \mathrm{D}$ and $\mathrm{J}$ regions and removing the unwanted intergenic regions of the sequence (the so-called "mini-gene" approach). Regeneron argued that the mouse regions could be deleted in one step and human V regions $(10 \mathrm{~kb})$ could be added in another step.

Kymab argued that Regeneron was too late in raising the mini-gene approach; however, the Court of Appeal allowed this submission stating that Regeneron had previously argued that the claims did not require the deletion of the entire mouse locus and the insertion of the entire human locus and that shorter sequences, in the form of mini-genes, could be used. Carr J did not decide on the issue of mini-genes in his first instance judgment.

The Court of Appeal, based on Kymab's experts' evidence, decided that the mini-gene concept was common general knowledge at the priority and that the skilled team would have recognised that the method in Example 3 could be performed using a VDJ mini-gene without undue burden. Whilst the Court of Appeal did not disagree with Carr J's finding that Example 3 would not have worked, or that the skilled person at the priority date would not have known how to delete and insert such large DNA sequences, it did note that the skilled person would not have been obliged to carry out the invention exactly as described in Example 3. The skilled person would have been able to use their common general knowledge to make obvious modifications.

Thus, the Court of Appeal concluded that the patents were sufficient (in line with the decisions of the EPO on these patents). Kitchin LJ (as he then was) giving the judgment goes into some depth discussing the state of the law on insufficiency ${ }^{36}$ endorsing his previous statement in Regeneron Pharmaceuticals Inc. v. Genentech Inc. ${ }^{37}$ that

[i]t must therefore be possible to make a reasonable prediction the invention will work with substantially everything falling within the scope of the claim or, put another way, the assertion that the invention will work across the scope of the claim must be plausible or credible. The products and methods within the claim are then tied together by a unifying characteristic or a common

\footnotetext{
36 Supra note 4, para. [208] et seq.

37 [2013] R.P.C. 28.
} 
principle. If it is possible to make such a prediction then it cannot be said the claim is insufficient simply because the patentee has not demonstrated the invention works in every case. ${ }^{38}$

Thus, a patent disclosing an invention of broad application may encompass embodiments which may be established in the future and which have advantageous properties, provided that those embodiments embody the technical contribution made by the invention - "[a] claim is not insufficient simply because it encompasses inventive improvements provided they embody the technical contribution the disclosure of the invention has made to the art". 39 A patent teaching a "big" invention will not necessarily be deemed to be insufficient if the scope of the invention is not fully known at the priority date. In this case, there was no question that Regeneron's invention had revolutionised the production of antibodies and had become the gold-standard for antibody production and the Court recognised that this deserved patent protection.

In addition to considering insufficiency the Court of Appeal also considered the issues of claim construction (the meaning of "in situ") and infringement. The issue of claim construction was dealt with far more straightforwardly by the Court of Appeal. The issue turned on the fact that Kymab's mice differ from the VelocImmune mice in that the mouse variable gene segments are not deleted in Kymab's mice, they are inactivated and flipped to a different part of the gene. Kymab argued that the method used to produce its mice did not amount to "in situ" replacement as this would require the deletion of the mouse variable region. However, Regeneron argued that "in situ" replacement merely requires "positional replacement", i.e. replacement in the position of the mouse variable sequence and deletion is not necessary. Regeneron used the analogy of a person being replaced at the front of a queue; their removal from the queue is not necessary in order to replace them at the front.

The Court of Appeal adopted a purposive construction and agreed with Regeneron that there was no teaching in the specification of the patents that required the mouse variable segments to be deleted or inactivated and that the skilled person would understand that the benefits of the invention could still be achieved without deleting the displaced mouse sequence. The Court of Appeal did not accept Kymab's argument that just because all of the examples in the specification included deletion of the mouse sequence, the claim should be limited to this. The Court of Appeal said that just because examples show one type of replacement does not mean that the claims are so restricted.

As a result of the Court of Appeal's construction of the claim, it was found that Kymab's mice infringe the product claims of Regeneron's patents (as the High Court had found). However, Kymab's processes were not held to infringe the processes set out in Regeneron's patents because they did not use the LTVEC or MOA assay. The Court of Appeal sidestepped the issue of the doctrine of equivalents as set out in Actavis v. Eli Lilly ${ }^{40}$; the Court stated that given that

\footnotetext{
38 Ibid, para. [100].

39 Supra note 4, para. [249].

40 Supra note 25.
} 
Kymab's mice infringe as a matter of normal construction, it was not necessary to consider equivalent variants.

\section{Jushi Group Co Ltd v. OCV Intellectual Capital LLC}

In Jushi Group Co Ltd v. OCV Intellectual Capital LLC, ${ }^{41}$ the Court of Appeal considered the issue of whether a numerical range can be novel if it overlaps with a previously disclosed numerical range. The case concerned OCV's patent for glass fibres, namely glass reinforcement strands. Claim 1 of the patent specified a glass strand made up of different constituents at percentage weights within specific ranges. The Court of Appeal had to determine whether it was novel and inventive in light of one piece of prior art. Jushi, a fibreglass manufacturer, brought an action for revocation of OCV's patent.

The prior art was actually cited by the patent and disclosed glass compositions made up of the same compounds as the patent and at the same or overlapping percentage weights. Thus, the main issue facing the Court of Appeal (and, indeed, that had faced the Intellectual Property Enterprise Court (IPEC) at first instance) was whether the ranges disclosed in the prior art that overlapped with those disclosed in the patent were novelty destroying.

Prior to this decision, the UK courts had previously voiced concerns with the EPO's approach to the novelty of overlapping ranges. The EPO approach requires that the overlapping range would not have been seriously contemplated by a skilled person in view of the prior art range and that selection of the range should have a technical effect. Whereas, it had been observed obiter by Floyd J (as he then was), that the UK courts' approach was that an overlapping range was novel only on the basis that it was a narrower selection. ${ }^{42}$

At first instance in the IPEC, ${ }^{43}$ HHJ Hacon concluded that the additional requirement of "seriously contemplated" utilised by the EPO was necessary to come to a decision on the novelty of overlapping ranges. Because this case involved 13 overlapping ranges, both parties presented expert evidence in an attempt to calculate the total percentage overlap across all of the multiple ranges. Both experts disagreed and HHJ Hacon said he was unable to determine a total percentage overlap and he was "left with no useful idea, not even a vague one" as to whether a skilled person would seriously contemplate "juggling all 13 ranges in such a way as to arrive at something within claim 1 of the Patent". ${ }^{44}$ As such, HHJ Hacon concluded that claim 1 was novel.

The Court of Appeal also came to find that claim 1 was novel; however, the reasoning differed from first instance. Floyd LJ applied the "seriously contemplated" EPO approach and concluded that a skilled person would expect small changes in the constituent percentages to have great (non-linear) effects on the glass

\footnotetext{
41 [2018] EWCA Civ 1416.

42 Lundbeck v. Norpharma SpA [2011] EWHC 907 (Pat), paragraph [89].

43 Jushi Group Co Ltd v. OCV Intellectual Capital LLC [2017] EWHC 171 (IPEC).

44 ibid, para. [77].
} 
fibres. Floyd LJ noted that he would only take objection to the EPO's "serious contemplation" test if it was "intended to relax the rigor of the general law of novelty" ${ }^{45}$; however, here, he accepted Jushi's argument that this test in the case of overlapping ranges was no different to the law of novelty as set out in Synthon $B V v$. SmithKline Beecham Plc (No. 2). ${ }^{46} \mathrm{He}$, thus, concluded that a skilled person would not understand the prior art as teaching that one can haphazardly select a combination of values from the disclosed ranges. However, Floyd LJ did not follow the EPO approach of determining whether the overlapping ranges have a technical effect.

This decision clearly moves the UK approach to overlapping numerical ranges more closely towards the EPO position; namely that a range should not have been seriously contemplated by a skilled person in light of the prior art in order to be novel. However, it does not achieve full alignment.

\section{Hospira UK Limited v. Cubist Pharmaceuticals LLC}

In Hospira UK Limited v. Cubist Pharmaceuticals $L L C^{47}$ a two judge panel (Lewison LJ and Kitchin LJ (as he then was)) of the Court of Appeal upheld Carr J's first instance decision ${ }^{48}$ that Cubist's patent for a method of purification for the antibiotic daptomycin was obvious over the cited prior art.

At first instance, Carr $\mathrm{J}$ had found that three patents owned by Cubist were invalid but Cubist only appealed with respect to one of the three patents. The patent concerned in the appeal related to a method of purification for daptomycin, a surfactant. It taught to lower the $\mathrm{pH}$ of a solution containing daptomycin thus changing the critical micelle concentration or $\mathrm{CMC}$, allowing the monomeric daptomycin molecules to group together to form micelles, and allowing contaminant particles smaller than the micelles to be filtered out. The $\mathrm{pH}$ would then be increased, changing the $\mathrm{CMC}$ and allowing the daptomycin to return to its monomeric state, then allowing contaminants larger than the monomers to be filtered out.

This purification process had been disclosed in the prior art in relation to the surfactant surfactin, rather than daptomycin, and the CMC was adjusted using methanol, rather than changing the $\mathrm{pH}$.

At first instance Carr $\mathrm{J}$ had applied the legal principles regarding obviousness set out in MedImmune Ltd v. Novartis Pharmaceuticals UK Ltd ${ }^{49}$ and Hospira UK Ltd $v$. Genentech Inc. ${ }^{50}$ On appeal, the parties did not dispute that these were the relevant legal principles; however, Cubist claimed that Carr $\mathrm{J}$ had been wrong to find that: (i) the skilled team would have considered daptomycin to be a micelle-

\footnotetext{
45 Supra note 43, para. [51].

46 [2006] All E.R. 685.

47 [2018] EWCA Civ 12.

48 Hospira UK Limited v. Cubist Pharmaceuticals LLC [2017] R.P.C. 10.

49 [2013] R.P.C. 27.

50 [2017] R.P.C. 13.
} 
forming surfactant; and (ii) that the skilled team would have thought the CMC could be adjusted by changing the $\mathrm{pH}$. Kitchin LJ (as he then was), giving the leading judgment for the Court of Appeal, found that Carr J had not erred in his findings or application of the principles relating to expectation of success, and upheld Carr J's finding of obviousness.

\section{Unwired Planet International Ltd v. Huawei Technology Co Ltd}

Unwired Planet International Ltd v. Huawei Technology Co Ltd ${ }^{51}$ (judgment by Kitchin LJ (as he then was) but contributed to by Floyd LJ and Asplin LJ) dealt with the appeal by Huawei and cross-appeal by Unwired Planet of Birss J's infamous decision on FRAND licences and FRAND injunctions in relation to Standard Essential Patents (SEPs). ${ }^{52}$ The Court of Appeal upheld Mr Justice Birss' decision on all substantive points appealed.

At first instance, Birss $\mathbf{J}$ found that only one set of FRAND terms existed and that this was a global licence between the parties. Birss $J$ set the rates which he considered the only FRAND terms. Huawei appealed the nature of the FRAND licence and objected to it being global in scope; however, Huawei did not appeal the actual rates that Birss $\mathbf{J}$ had set. Huawei argued that it is wrong in principle that a national court can impose upon parties a global licence on terms set by a national court based on a national finding of infringement. Huawei also submitted that Birss $\mathbf{J}$ had settled a licence regardless of the fact that there was ongoing patent litigation in relation to portfolio patents in Germany and China, and that there were a number of countries where Unwired Planet had no relevant patents.

In considering the issue of a global FRAND licence, the Court of Appeal recognised that it might be impractical for an SEP owner to negotiate a licence on a country-by-country basis and it might also be prohibitively expensive to litigate to enforce its patent rights on a country-by-country basis. Ultimately, the Court of Appeal agreed with Birss J's finding that a global licence was FRAND. The Court of Appeal was clear in stating that just because a global licence was determined to be FRAND, did not mean that Birss $J$ was making any determinations on the validity or infringement of foreign SEPs. The Court of Appeal said that Birss $\mathbf{J}$ had merely determined the licence that Unwired Planet was required to offer to Huawei in order to meet its undertaking to ETSI. The Court of Appeal said that Huawei had a choice of whether to take the licence or not and that it could not be compelled to take it. It was also made clear that if Huawei did not take the licence then the only relief for infringement that would be available to Unwired Planet was in respect of the two UK SEPs Birss $J$ had found valid and essential at first instance.

The Court of Appeal did disagree with Birss J's finding that there is only one set of FRAND terms in any specific scenario; however, it was found that this did not have a measurable impact on Birss J's decision. The Court of Appeal concluded that it was unreasonable and did not match the commercial realities of negotiating

\footnotetext{
${ }^{51}$ [2018] EWCA Civ 2344.

${ }^{52}$ Unwired Planet International Ltd v. Huawei Technology Co Ltd [2017] EWHC 711 (Pat).
} 
complex licences to suggest that two parties acting fairly and reasonably would arrive at the same set of licence terms as two other parties also acting fairly and reasonably. The Court of Appeal also addressed a market concern of which licence prevails if a FRAND offer is made by the SEP owner and a lower counteroffer by a potential licensee is also FRAND. The Court determined that if a global and a national licence are both FRAND then it is up to the SEP owner to choose which FRAND terms it makes available to the potential licensee, i.e. it is free to offer only a global licence if it wishes.

Huawei also argued that the "Non-Discriminatory" part of FRAND necessitated that rates given to similarly positioned licensees should apply across the industry. Prior to the trial, Huawei's co-defendant Samsung had settled with Unwired Planet for a lower rate; Huawei argued that it would be discriminatory if they had to pay more than Samsung. At first instance, Birss J said that a licensee should not be able to demand a lower rate simply because such a rate had previously been given to a similarly situated licensee. Birss J said that FRAND does not have a "hard edged" component that would justify this. He said that as there was no "hard edged" component, an SEP holder would only be obliged to offer the same rate if the difference in rates would lead to a distortion of competition between the two licensees. In this case, there was no such evidence.

The Court of Appeal agreed with Birss J's findings regarding the "NonDiscrimination" aspect of FRAND not being "hard edged". The Court held that a "hard edged" approach could actually have a negative effect on the technological development of standards as the approach is overly strict and does not allow a balance to be struck between a fair return to the SEP owner and universal access to technology without the threat of an injunction.

In Unwired Planet's cross-appeal, it challenged Birss J's assumption that it held a dominant position, which would necessitate the application of Huawei v. ZTE. ${ }^{53}$ The Court of Appeal dismissed this cross-appeal. The Court of Appeal declared that the CJEU in Huawei v. ZTE was not specifying mandatory steps which must be completed before an SEP holder issues proceedings for injunctive relief. Instead, it said, the CJEU merely set out a safe harbour for SEP holders which, if followed, meant it could not be deemed to have acted abusively. The Court of Appeal said that just because an SEP holder is outside of the Huawei v. ZTE safe harbour, it does not mean the party's behaviour is an abuse of dominance. The Court of Appeal said that Unwired Planet was not refusing to license its SEPs as, before it issued proceedings, Huawei was aware or ought to have been aware that Unwired Planet held SEPs and that if these were truly essential and valid, then Huawei would have to take out a licence. The Court said that Huawei also knew that Unwired Planet wanted to licence with it. The Court of Appeal thus agreed with Birss J's conclusion that Huawei did not have an automatic defence in Huawei v. ZTE and Unwired Planet did not act in an abusive manner. It is worth noting that the Court of Appeal did acknowledge that this present litigation actually started before the CJEU gave its judgment in Huawei v. ZTE and therefore said it would have been unfair to hold

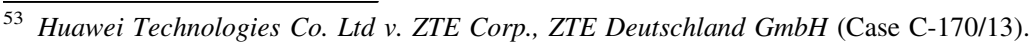


Unwired Planet as acting abusively by not complying with requirements that were only laid down at a subsequent time.

This hotly anticipated decision has been good news for SEP owners but, naturally, less favourable for potential SEP licensees. The English courts have asserted England as a premier jurisdiction in which to settle global licensing disputes, of course, provided that the potential licensee has enough incentive not to just exit the UK market rather than take a licence on the terms determined by the English courts.

\section{Conversant Wireless Licensing SARL v. Huawei Technologies and Ors}

In another FRAND related decision, Carr J in Conversant Wireless Licensing SARL v. Huawei Technologies and Ors $^{54}$ rejected Huawei's and ZTE's challenge to the English courts' jurisdiction to determine a global FRAND licence when relevant UK sales amounted $1 \%$ or less of worldwide sales on which Conversant claimed royalties.

Huawei and ZTE challenged the jurisdiction of the English courts to hear Conversant's claim on the basis of two main arguments: (i) justiciability - the English court has no jurisdiction to decide these claims as they are, in substance, claims for infringement of foreign patents, the validity of which is in dispute; and, in the alternative, (ii) forum non conveniens - if the English courts do have jurisdiction to hear the claim, then they should decline it because England is not the most appropriate forum to hear the claim, rather, China is.

In relation to the Defendants' justiciability arguments, the Patents Court accepted that the English courts could not determine the validity of foreign patents and the Defendants argued that this, in fact, was the substance of Conversant's claim. Carr J did not find the Defendants' arguments in this respect persuasive and said that if a worldwide licence was FRAND then requiring the Defendants to take one does not amount to determining validity or essentiality of foreign patents over which other courts have exclusive jurisdiction. By taking a global FRAND licence, Carr J said that the licensee is not prevented from challenging the validity and essentiality of foreign patents in other courts. In this case, the Defendants each have validity challenges ongoing in China, which are due to finish before the English FRAND trial commences in 2020, and Carr J said that the English courts could take the decisions of the Chinese courts into account in the FRAND trial. Carr $J$ also said that any licence determined would also contain a mechanism for dealing with patents that are held to be invalid after the licence is entered into, i.e. there would be a mechanism to reduce the royalty rates.

In relation to the Defendants' alternative arguments concerning forum non conveniens, the Defendants argued on the basis of the principles set out in Spiliada Maritime Corp v. Cansulex Ltd. ${ }^{55}$ The Defendants said that Conversant was seeking only to obtain a global FRAND licence and was using the UK patents as a hook

\footnotetext{
${ }^{54}$ [2018] EWHC 808 (Pat).

55 [1987] AC 460.
} 
upon which to hang their whole case of enforcing a global FRAND licence. The Defendants also offered to have a global FRAND rate set in China by the Chinese courts.

The Claimant referred to the principles in Owusu v. Jackson ${ }^{56}$ which, it said, would mean that its claim regarding the UK patents would remain in the English courts and lead to bifurcated proceedings in different jurisdictions. The Claimant also raised concerns over whether the Chinese courts actually have jurisdiction to and are able to determine global FRAND licences and/or infringement of nonChinese patents.

Carr J strongly sided with the Claimant, including in his reasoning that he felt that the Chinese courts do not have jurisdiction to determine the terms of a global FRAND licence nor can they determine the infringement of UK patents. Carr J also said that the Claimant's claims were, in fact, claims for the infringement of four UK patents, and this was so regardless of the fact that ultimately the Claimant sought either a global FRAND licence or a FRAND injunction.

The Patents Court resoundingly rejected the Defendants' jurisdiction challenge in this case and it seems unlikely that the English courts would decline jurisdiction in a case with a UK patent at issue regardless of how small a percentage the relevant UK sales constitute of the worldwide turnover. We will have to wait to see what is next for Huawei in light of these two decisions this year.

\section{AP Racing Ltd v. Alcon Components Ltd}

In AP Racing Ltd v. Alcon Components Ltd, ${ }^{57}$ the Court of Appeal dismissed a second appeal brought by AP Racing concerning brake calipers used in motorsports, upholding a decision by HHJ Hacon in the IPEC that two versions of brake calipers manufactured by Alcon did not infringe AP Racing's patent. ${ }^{58}$ Note that Alcon did not appeal HHJ Hacon's previous finding that one of the eight brake calipers in dispute did infringe AP Racing's patent.

The patent in suit was originally held invalid for added matter ${ }^{59}$ but this was overturned on appeal. ${ }^{60}$ AP Racing then brought a second action in which it claimed that a number of Alcon's brake calipers infringed the upheld patent. At a second trial in the IPEC, HHJ Hacon held that all but one of the brake calipers did not infringe AP Racing's patent. The Court of Appeal upheld HHJ Hacon's judgment. The Court of Appeal pointed to AP Racing's previous (numerous) attempts to identify an essential element of the claims in Alcon's alleged infringing device; the Court thought this showed a lack of clarity. Whilst the Court of Appeal acknowledged that this was not a statutory ground for revoking a patent, it said

\footnotetext{
56 [2005] Q.B. 801.

57 [2018] EWCA Civ 1420.

58 AP Racing Ltd v. Alcon Components Ltd [2017] EWHC 248 (IPEC).

${ }^{59}$ AP Racing Ltd v. Alcon Components Ltd [2013] EWPCC 3.

${ }^{60}$ AP Racing Ltd v. Alcon Components Ltd [2014] R.P.C. 27. This is now the leading case on added matter.
} 
that it could make it difficult for a patentee to establish infringement. The Court of Appeal decided that HHJ Hacon had done his best to apply the elements in the patent specification to the accused brake calipers and therefore he had made a value judgment. The Court of Appeal felt that the appeal was merely a disagreement with HHJ Hacon's value judgment and that an appeal court ought to be cautious in interfering in value judgments of this kind.

The Court of Appeal further found that the new arguments AP Racing had put forward on appeal should not be permitted, particularly as the appeal was from the IPEC where the rules require that all arguments being put forth must be identified in the pleadings. The Court of Appeal made it clear that the job of an appeal court is not to try a case again but to review the decision of a trial judge and allowing a party to present an appeal court with a new case does not meet this role.

\section{Clearswift Ltd v. Glasswall (IP) Ltd}

Finally, in Clearswift Ltd v. Glasswall (IP) $L t d,{ }^{61}$ Clearswift, an anti-malware provider, challenged the validity of a patent owned by Glasswall (IP) Ltd for lack of inventive step over two pieces of prior art. At the priority date of the patent, the majority of antimalware software scanned incoming files and blocked all or part of the file if it detected evidence of malware. These systems could only scan for known malware and therefore could not scan for new malware unless and until the software was updated.

Glasswall, however, claimed that its patent took a different approach and instead taught "parsing" and "regeneration" of each file (i.e. breaking down and rebuilding the file so that only "good" code (not malware) is passed on and the malware or "bad" code is left behind). This parsing and regeneration occurred regardless of whether any malware was detected.

Clearswift cited a US patent published seven weeks before Glasswall's patent and a series of posts from an internet bulletin board which discussed the Glasswall software available at that time. As such, Clearswift asserted that there was no inventive step over the US patent or the bulletin board posts. Clearswift alleged that the US patent and Glasswall's patent did the same thing in the same manner and that the bulletin board discussion disclosed the whole of the relevant claim in Glasswall's patent.

Both parties called one expert each. Mr David Stone (sitting as Deputy Judge of the High Court (Chancery Division)) felt that both experts attempted to assist the Court and explain technical details as necessary but that neither expert was an approximation of the skilled person. Mr Stone said that one was too skilled and was himself inventive (Clearswift's expert) and the other had never worked in industry (Glasswall's expert). Despite this, Mr Stone was satisfied that both experts were able to assist the Court's understanding of the technology.

In assessing obviousness, Mr Stone followed Pozzoli SpA v. BDMO SA, ${ }^{62}$ where Jacob LJ set out the following steps: (i) identify the notional "person skilled in the

\footnotetext{
${ }^{61}$ [2018] EWHC 2442 (Pat).

62 [2007] F.S.R. 37.
} 
art"; (ii) identify the relevant common general knowledge of that person; (iii) identify the relevant inventive concept of the claim in question or if that cannot be readily done, construe it; (iv) identify what, if any, differences exist between the matter cited as forming part of "the state of the art" and the inventive concept (as identified or construed); and (v) viewed without any knowledge of the alleged invention as claimed, do those differences constitute steps that would have been obvious to the person skilled in the art or do they require a degree of invention? $\mathrm{Mr}$ Stone found that the skilled person was a person with a computer science degree with between one and three years' experience working in the anti-malware software industry. Mr Stone held that the relevant common general knowledge was knowledge of anti-malware techniques used at the relevant time due to an increase in the amount of malware around, including computer viruses.

In identifying the inventive concept of Glasswall's patent, $\mathrm{Mr}$ Stone also followed Pozzoli, which set out that in the event of disagreement on the issue, the court should work on the features of the claim. In construing the patent, Mr Stone favoured Glasswall's interpretation. Mr Stone found that parsing and regeneration were key features of Glasswall's patent and that they were not identified in the US patent. Mr Stone concluded that this was "a significant difference that would not have been obvious to the skilled addressee". ${ }^{63}$ With regard to the bulletin board posts, Mr Stone concurred with Glasswall that it would have been difficult for the skilled person to ascertain much from them that was "clear and unmistakable". 64 Consequently, Mr Stone found that Glasswall's patent was not obvious over the prior art and Clearswift's application for revocation was dismissed. This decision reinforces Pozzoli's authority on obviousness and provides some insight into the knowledge and experience experts need in order for them to be approximate representations of the skilled person.

Open Access This article is distributed under the terms of the Creative Commons Attribution 4.0 International License (http://creativecommons.org/licenses/by/4.0/), which permits unrestricted use, distribution, and reproduction in any medium, provided you give appropriate credit to the original author(s) and the source, provide a link to the Creative Commons license, and indicate if changes were made.

Publisher's Note Springer Nature remains neutral with regard to jurisdictional claims in published maps and institutional affiliations.

\footnotetext{
63 Supra note 61, para. [133].

64 Supra note 61, para. [147].
} 